\title{
Intramuscular deposit of calcium is a potential reason for hypocalcaemia in COVID-19
}

\author{
Johannes Kalbhenn $\mathbb{1}^{1} \cdot$ Julian Knoerlein ${ }^{1}$
}

Received: 11 February 2021 / Accepted: 23 March 2021 / Published online: 8 April 2021

(c) The Author(s) 2021

To the Editor:

With great interest we read the letter of Singh et al. specifying several aetiologies for hypocalcaemia in coronavirus disease 19 (COVID-19) patients [1]. Hypocalcaemia is common in COVID-19 [1] and associated with decreased survical [2]. In the following by reporting the case of a patient treated with severe COVID-19 at our department we propose an additional mechanism leading to hypocalcaemia: a 44-year-old male patient with severe respiratory failure due to COVID-19 was referred to the intensive care unit for extracorporeal membrane oxygenation. On admission he presented with hypocalcaemia probably caused by the abovementioned mechanisms. During the first four weeks of therapy he needed excessive substitution of calcium-gluconate to keep serumcalcium level within the normal range (Fig. 1). Overall, more than $5.400 \mathrm{ml}$ of calcium-gluconate $10 \%$ solution had to be infused. Computed tomography of the abdomen two weeks after referral coincidentally showed cloudy radiopaque deposits in the midst of the gluteal muscles (Fig. 2B) which were most likely caused by calcium. Compared to the computed tomography on admission (Fig. 2A) this was a new finding. We believe that precipitation of calcium in the muscle was aggravated by the excessive substitution of calcium-gluconate solution during therapy.

We found calcium precipitates also in the deltoid muscle but not in other organs. COVID-19 often is accompanied by myositis [3]. It is obvious that negatively charged valences, for example, from myoglobin are presented when muscle tissue loses its integrity and that calcium ions may accumulate and calcium salts may precipitate especially in these regions. Precipitation of calcium should be considered an additional possible reason for hypocalcaemia in COVID-19.

Johannes Kalbhenn

Johannes.kalbhenn@uniklinik-freiburg.de

1 Department of Anaesthesiology and Critical Care, Medical Center -University of Freiburg, Faculty of Medicine, University of Freiburg, Freiburg, Germany 

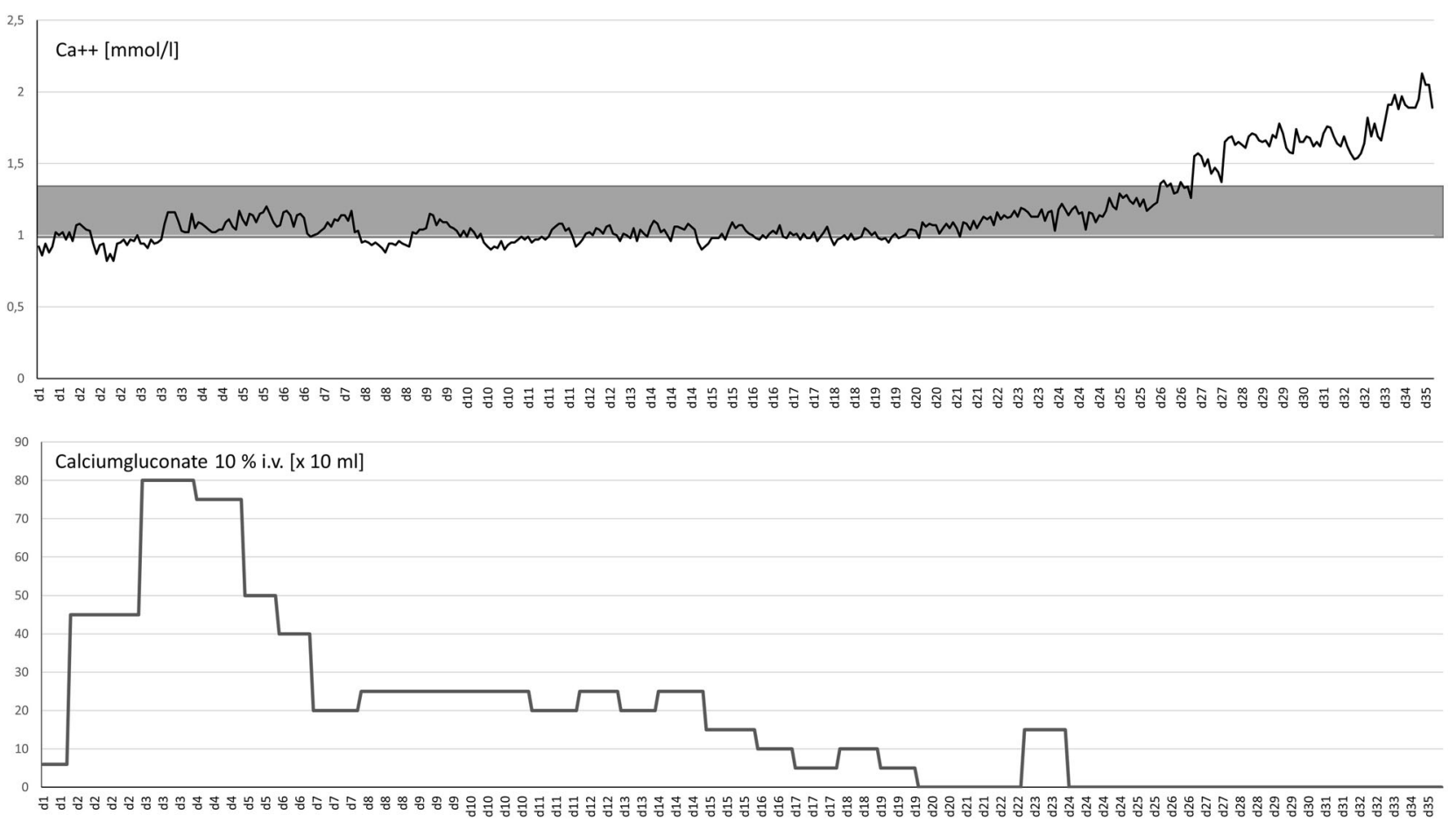

Fig. 1 Upper graph: Serum-concentration of calcium from day 1 to day 35 of treatment (grey area indicating normal range). Lower graph: Amount of substituted calcium-gluconate $10 \%$ solution per day

Fig. 2 Computed tomography on admission (panel $\mathbf{A}$ ) and 2 weeks later (panel B). White arrows indicating radiopaque depots of precipitated calcium within gluteal muscles

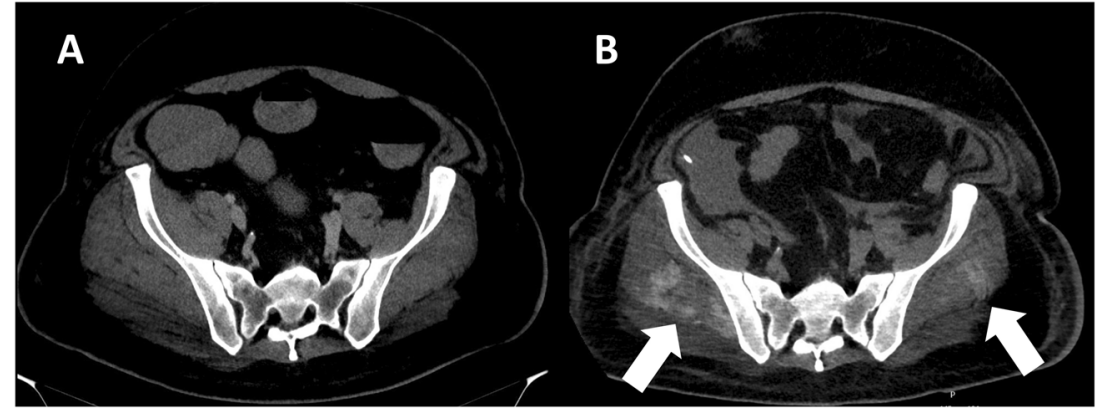

\section{Data availability}

On request.

Author contributions J.K. and J.K. both precipitated equally in writing and editing the manuscript.

Funding Open Access funding enabled and organized by Projekt DEAL.

\section{Compliance with ethical standards}

Conflict of interest The authors declare no competing interests.

Informed consent Legal representative of the patient gave informed consent.

Publisher's note Springer Nature remains neutral with regard to jurisdictional claims in published maps and institutional affiliations.
Open Access This article is licensed under a Creative Commons Attribution 4.0 International License, which permits use, sharing, adaptation, distribution and reproduction in any medium or format, as long as you give appropriate credit to the original author(s) and the source, provide a link to the Creative Commons license, and indicate if changes were made. The images or other third party material in this article are included in the article's Creative Commons license, unless indicated otherwise in a credit line to the material. If material is not included in the article's Creative Commons license and your intended use is not permitted by statutory regulation or exceeds the permitted use, you will need to obtain permission directly from the copyright holder. To view a copy of this license, visit http://creativecommons. org/licenses/by/4.0/.

\section{References}

1. V.P. Singh, B. Khatua, B. El-Kurdi, C. Rood, Mechanistic basis and therapeutic relevance of hypocalcemia during severe COVID19 infection. Endocrine 70(3), 461-462 (2020) 
2. L. di Filippo, A.M. Formenti, M. Doga, S. Frara, P. Rovere-Querini, E. Bosi, M. Carlucci, A. Giustina, Hypocalcemia is a distinctive biochemical feature of hospitalized COVID-19 patients. Endocrine 71(1), 9-13 (2021). https://doi.org/10.1007/s12020-020-02541-9
3. A.N. Duarte-Neto, R.A.A. Monteiro, L.F.F. da Silva, D. Malheiros, E. P. de Oliveira, J. Theodoro-Filho et al. Pulmonary and systemic involvement in COVID-19 patients assessed with ultrasound-guided minimally invasive autopsy. Histopathology 77(2), 186-197 (2020) 